\title{
Penetration by field vole spermatozoa of mouse and hamster zonae pellucidae without acrosome reaction
}

\author{
T. Wakayama ${ }^{1}$, A. Ogura ${ }^{2}$, J. Suto ${ }^{3}$, Y. Matsubara ${ }^{3}$, M. Kurohmaru ${ }^{1}$, \\ Y. Hayashi ${ }^{1}$ and R. Yanagimachi ${ }^{4}$ \\ ${ }^{1}$ Department of Veterinary Anatomy, Faculty of Agriculture, The University of Tokyo, Bunkyo-ku, \\ Tokyo 113, Japan; ${ }^{2}$ Department of Veterinary Science, Japan's National Institute of Health, Shinjuku-ku, \\ Tokyo 162, Japan; ${ }^{3}$ National Institute of Animal Health, Tsukuba, Ibaraki 305, Japan; and \\ ${ }^{4}$ Department of Anatomy and Reproductive Biology, University of Hawaii School of Medicine, \\ Honolulu, HI 96822, USA
}

\begin{abstract}
Spermatozoa of the field vole (Microtus montebelli) that bound to the zona pellucida of field vole oocytes underwent the acrosome reaction before passing through it. In contrast, vole spermatozoa that bound to the zonae of mouse and hamster oocytes penetrated the zonae without any sign of the acrosome reaction. The presence or absence of proteinasel hyaluronidase inhibitors in the medium did not make any difference to zona penetration by acrosome-intact vole spermatozoa. These observations suggest that field vole spermatozoa can cross mouse and hamster zonae mechanically without assistance from zona-hydrolysing enzymes.
\end{abstract}

\section{Introduction}

Mammalian oocytes are each surrounded by a glycoprotein coat, the zona pellucida, which protects fragile oocytes and developing preimplantation embryos during their descent through the oviduct. Under natural conditions, the fertilizing spermatozoon must cross the zona before reaching and fusing with the plasma membrane of the oocyte. The mechanism by which spermatozoa penetrate through the zona is not fully understood. While it is a popular notion that acrosomal enzymes (for example, acrosin) tightly bound to the inner acrosomal membrane of acrosome-reacted spermatozoa depolymerize zona glycoproteins (for example, O'Rand et al., 1986), the vigorous thrusting motion of the sperm head may play an equally important role in this process (Bedford, 1991; Yanagimachi, 1994).

We have reported that the spermatozoa of the field vole penetrate not only the zona of homologous species (Wakayama et al., 1995a, b), but also zonae of heterologous species such as mice and hamsters (Wakayama et al., 1993). Here, we report that while field vole spermatozoa cross the vole zonae after completing the acrosome reaction, they pass through mouse and hamster zonae without the acrosome reaction.

\section{Materials and Methods}

\section{Animals}

The field vole (Microtus montebelli) used in this study has been bred in the Japan's National Institute of Animal Health at Tsukuba for over 20 years. It is a herbivorous rodent that can

Received 10 October 1995. be used as an animal model for various physiological studies of herbivorous farm animals (Goto et al., 1977; Goto and Hashizume, 1978; Kudo and Oki, 1984; Imai and Ogimoto, 1988; Obara and Goto, 1988). Voles were maintained in a temperature-controlled $\left(25^{\circ} \mathrm{C}\right)$ room with $14 \mathrm{~h}$ light: $10 \mathrm{~h}$ dark cycles. Females were used before reaching puberty $(<4$ weeks after birth). Mice (ICR) and the golden hamsters maintained under the same conditions as described above were used after full maturity ( $>2$ and 3 months of age, respectively).

\section{Reagents}

All inorganic and organic compounds were purchased from Sigma Chemical Co. (St Louis, MO) unless otherwise stated. Myocrisin (gold sodium thiomalete; hyaluronidase inhibitor) was the gift from Merck Sharp and Dohme Research Laboratory (Rahway, NJ). Soybean trypsin inhibitor (SBTI) and leupeptin (Wako Chemical, Tokyo) were used as proteinase inhibitors.

\section{Medium}

A modified Krebs'-Ringer's solution, mKRB (Toyoda and Chang, 1974), was used for handling vole oocytes and spermatozoa. In some experiments this medium was supplemented with $1 \mathrm{mmol}$ hypotaurine $\mathrm{I}^{-1}$. TYH medium (Toyoda et al., 1971) was used for insemination of mouse oocytes with mouse spermatozoa.

\section{Preparation of oocytes}

Immature female voles and mature female mice and hamsters were induced to superovulate by consecutive 
injections of pregnant mares' serum gonadotrophin (PMSG) and hCG at an interval of $48 \mathrm{~h}$. The doses of PMSG and hCG were $30 \mathrm{iu}$ and $30 \mathrm{iu}$ for the vole and hamster, and $5 \mathrm{iu}$ and $5 \mathrm{iu}$ for the mouse, respectively. Mature unfertilized oocytes of field voles and mice were collected from oviducts 13-16 h after hCG injection. Hamster oocytes were collected 15-17 h after hCG injection. Mouse zygotes (pronuclear eggs) and two-cell embryos were collected from oviducts of mated, superovulated mice $14 \mathrm{~h}$ and $38 \mathrm{~h}$ after hCG injection, respectively. Eggs (oocytes with cumulus cells, zygotes or two-cell embryos) were collected from oviductal ampullae and transferred into droplets $(100 \mu \mathrm{l})$ of fresh mKRB which had been previously placed under mineral oil in a plastic Petri dish (35 mm diameter). The medium in the dish had been equilibrated with $5 \% \mathrm{CO}_{2}$ in air for at least $2 \mathrm{~h}$ at $37^{\circ} \mathrm{C}$ before use.

\section{Preparation of spermatozoa}

Vole and mouse spermatozoa were collected from caudae epididymides of mature males. The distal portion of each epididymis was cut using a blade and a dense sperm mass was squeezed out of the epididymis. Spermatozoa were allowed to disperse into $200 \mu \mathrm{lmKRB}$. The concentration of spermatozoa

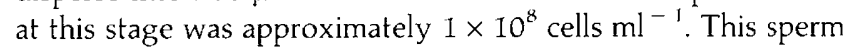
suspension was used for insemination immediately after preparation.

Insemination and examination of oocytes, zygotes or embryos in vitro

Insemination was performed by adding $1-10 \mu \mathrm{l}$ of vole sperm suspension to $100 \mu \mathrm{l} \mathrm{mKRB}$ containing either vole or hamster oocytes or mouse oocytes, zygotes and two-cell embryos. Final sperm concentrations in the insemination

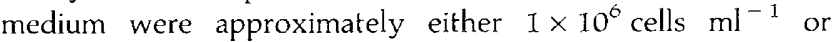
$10 \times 10^{\circ}$ cells $\mathrm{ml}^{-1}$. In some experiments, hyaluronidasel

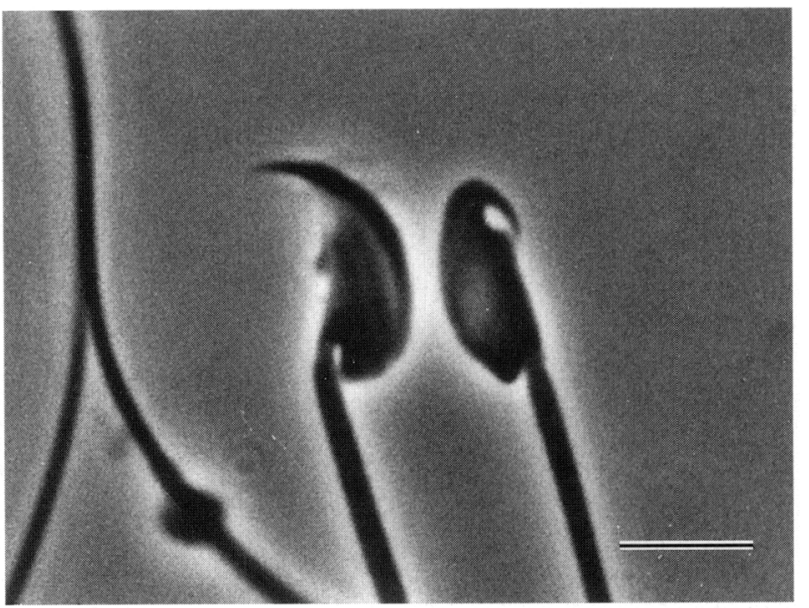

Fig. 1. Spermatozoa of the mouse (left) and the Japanese field vole (right). The field vole spermatozoon is slightly smaller than the mouse spermatozoon. Scale bar represents $5 \mu \mathrm{m}$.

proteinase inhibitors were incorporated into the insemination media. After incubation for $6 \mathrm{~h}$ at $37^{\circ} \mathrm{C}$ under $5 \% \mathrm{CO}_{2}$ in air, inseminated oocytes, zygotes or embryos were removed from the dishes and examined under a phase-contrast microscope for the presence or absence of spermatozoa within the perivitelline space. They were then fixed with $2.5 \%(\mathrm{v} / \mathrm{v})$ glutaraldehyde in $0.1 \mathrm{~mol}$ phosphate buffer $\mathrm{l}^{-1}$ for $2 \mathrm{~h}$, stained with $0.25 \%(\mathrm{v} / \mathrm{v})$ acetolacmoid (Toyoda et al., 1971) and examined for evidence of sperm penetration into the ooplasm. Some mouse oocytes were fixed with $2.5 \%(\mathrm{v} / \mathrm{v})$ glutaraldehyde for $2 \mathrm{~h}$ and processed for electron microscopy.

In a series of experiments, mouse oocytes that had been penetrated by vole spermatozoa were reinseminated with mouse spermatozoa. Mouse oocytes were first inseminated with field vole spermatozoa. Two hours later the oocytes with vole spermatozoa within their perivitelline space were selected under a dissecting microscope, washed with TYH medium and

Table 1. Penetration of field vole spermatozoa into field vole and mouse oocytes

\begin{tabular}{|c|c|c|c|c|c|}
\hline Oocytes of & $\begin{array}{l}\text { Concentration of vole } \\
\text { spermatozoa in } \\
\text { insemination medium } \\
\times 10^{6} \mathrm{ml}^{-1}\end{array}$ & $\begin{array}{c}\text { Presence }(+) \text { or } \\
\text { absence }(-) \text { of } \\
\text { I mmol hypotaurine }\left.\right|^{-1} \\
\text { in medium }\end{array}$ & $\begin{array}{l}\text { Total number } \\
\text { of oocytes } \\
\text { inseminated } \\
\text { (Expt number) }\end{array}$ & $\begin{array}{l}\text { Number }(\%) \text { o } \\
\text { spermat } \\
\text { Perivitelline } \\
\text { space }^{a}\end{array}$ & $\begin{array}{l}\text { cytes with } \\
\text { a in: } \\
\text { Vitellus }\end{array}$ \\
\hline \multirow[t]{4}{*}{ Vole } & \multirow[t]{2}{*}{1} & - & $69(5)$ & $33(47.8)$ & $33(47.8)$ \\
\hline & & + & $70(5)$ & $60(85.7)$ & $60(85.7)$ \\
\hline & \multirow[t]{2}{*}{10} & - & $68(5)$ & $15(22.1)$ & $I(1.5)$ \\
\hline & & + & $73(5)$ & $14(19.2)$ & $1(1.4)$ \\
\hline \multirow[t]{4}{*}{ Mouse } & \multirow[t]{2}{*}{1} & - & $93(5)$ & $15(16.1)$ & 0 \\
\hline & & + & $87(5)$ & $10(11.5)$ & 0 \\
\hline & \multirow[t]{2}{*}{10} & - & $90(5)$ & $87(96.7)$ & 0 \\
\hline & & + & $105(5)$ & $99(94.3)$ & 0 \\
\hline
\end{tabular}

a $P<0.05$, low versus high concentrations of spermatozoa in the vole and mouse; presence versus absence of hypotaurine in the vole for low concentration of spermatozoa.

${ }^{\mathrm{h}} \mathrm{P}<0.05$, low versus high concentrations of spermatozoa in the vole. 

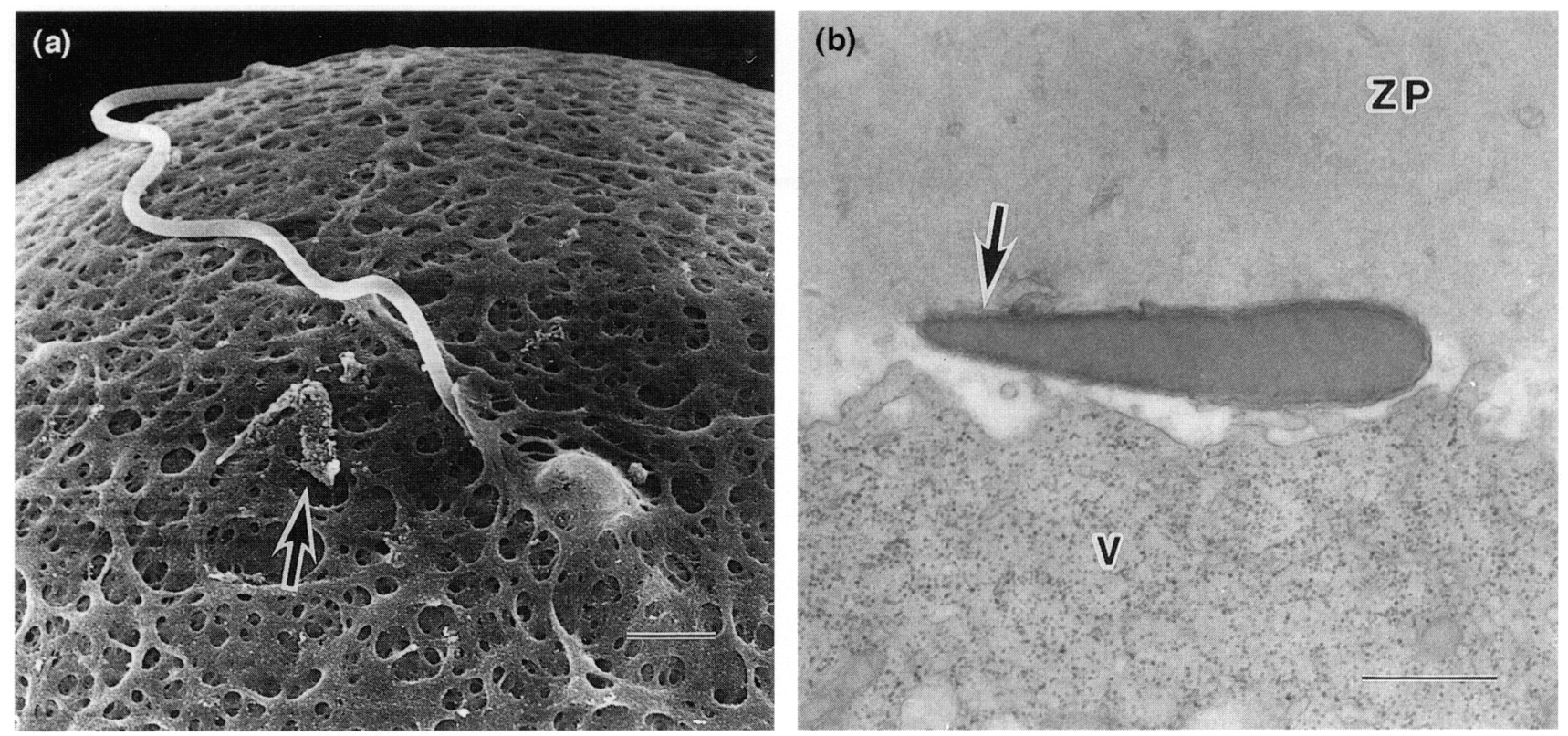

Fig. 2. (a) Field vole spermatozoon entering the zona pellucida of field vole oocyte $3.5 \mathrm{~h}$ after insemination. The sperm head is already within the zona. An arrow indicates the acrosomal ghost left on the zona. Scale bar represents $5 \mu \mathrm{m}$. (b) Semi-longitudinal section of field vole sperm head within the perivitelline space. An arrow indicates the inner acrosomal membrane of acrosome-reacted spermatozoon in the perivitelline space. V: oocyte vitellus; ZP: zona pellucida. Scale bar represents $1 \mu \mathrm{m}$.
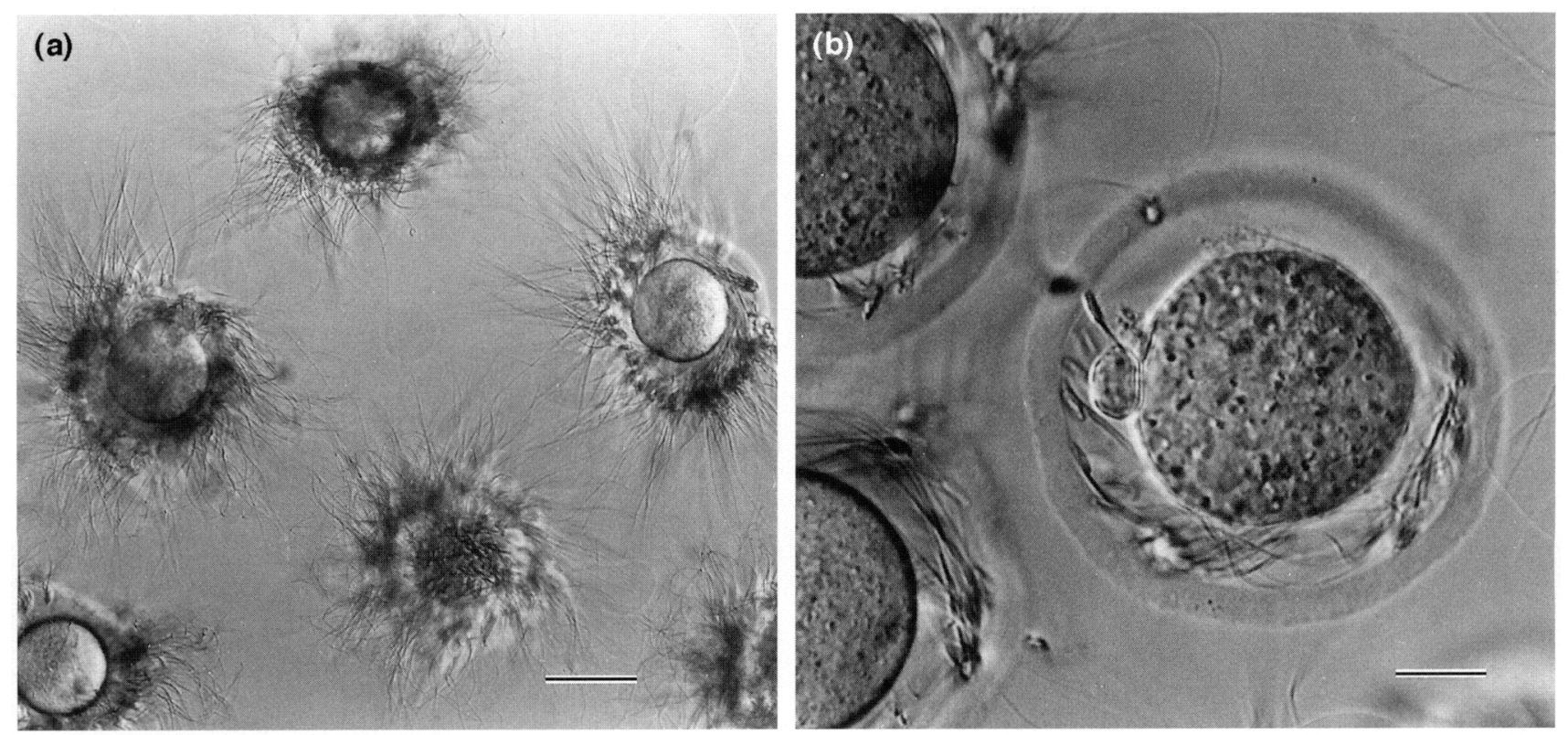

Fig. 3. (a) Mouse oocytes inseminated with field vole spermatozoa $6 \mathrm{~h}$ after insemination. Scale bar represents $70 \mu \mathrm{m}$. (b) Mouse oocyte showing field vole spermatozoa within the perivitelline space. Scale bar represents $25 \mu \mathrm{m}$.

reinseminated with fresh mouse spermatozoa in $100 \mu \mathrm{L}$ TYH medium. The concentration of mouse spermatozoa in reinsemination medium was $1 \times 10^{\circ}$ cells $\mathrm{ml}^{-1}$. The oocytes were re-examined $6 \mathrm{~h}$ later.

\section{Statistical analyses}

Each experiment was repeated 2-7 times. The data were analysed with ANOVA (Table 1) or chi-squared tests (Tables 2,
3 and 4). In Table 1 and 2, data for mouse oocytes and vole oocytes were analysed separately.

\section{Results}

The outer diameter and thickness of the zona pellucida of a mature field vole oocyte are about $90 \mu \mathrm{m}$ and $9-9.5 \mu \mathrm{m}$, respectively. Corresponding values for mouse and hamster 
zonae are about $100 \mu \mathrm{m}$ and $7.5 \mu \mathrm{m}$ (mouse) and $115 \mu \mathrm{m}$ and $13 \mu \mathrm{m}$ (hamster), respectively. In other words, field vole zonae are smaller and thicker than mouse zonae and smaller and thinner than hamster zonae. The vole spermatozoon is smaller than the mouse spermatozoon (Fig. 1). The width (including hook) and length of sperm head and the length of tail are approximately: $3.0 \mu \mathrm{m}, 7.5 \mu \mathrm{m}$ and $110 \mu \mathrm{m}$ for the vole; $3.5 \mu \mathrm{m}, 8 \mu \mathrm{m}$ and $120 \mu \mathrm{m}$ for the mouse; and $7 \mu \mathrm{m}, 9 \mu \mathrm{m}$ and $180 \mu \mathrm{m}$ for the hamster.

The results of experiments in which vole and mouse oocytes were inseminated in vitro with vole spermatozoa are summarized (Table 1). Upon insemination, vole spermatozoa bound to the zona surfaces of both vole and mouse oocytes. Vigorous pipettings could not remove them.

The largest population of vole oocytes were fertilized when the insemination medium contained 1 mmol hypotaurine $\mathrm{I}^{-1}$ and sperm concentration was approximately $1 \times 10^{6} \mathrm{cells}^{-1}$. The presence or absence of hypotaurine and the concentration of the spermatozoa each significantly affected the ferilization rate in voles $(P<0.05)$. Zona penetration by spermatozoa began about $2 \mathrm{~h}$ after insemination. Acrosomal ghosts left by the penetrating spermatozoa were seen on zona surfaces (Fig. 2a). As far as we could observe $(n=50)$, the spermatozoa within the zona and in the perivitelline space were all acrosome-reacted (Fig. 2b). The relatively thin zona in the electron micrographs, as compared with the sperm head, appears to be due to zona shrinkage that occurs during dehydration and embedding of specimens.

Vole spermatozoa that bound to mouse zona pellucida (Fig. 3a) could pass through it (Fig. 3b), but they failed to penetrate into (fuse with) the vitellus of mouse oocytes (Table 1). The incidence of mouse zona penetration by vole spermatozoa was dependent on sperm concentration $(P<0.05)$, but not on the presence or absence of hypotaurine. The acrosomal status of several thousand spermatozoa could be observed ultrastructurally from about 300 mouse oocytes. Vole spermatozoa within the mouse zona (Fig. 4a) and in the perivitelline space (Fig. 4b) all had intact acrosomes, regardless of the concentration of spermatozoa. The presence or absence of hyaluronidase/proteinase inhibitors in the insemination medium had no significant effect on mouse zona penetration by vole spermatozoa (Table 2). In the homologous insemination these inhibitors apparently decreased the incidence of penetration of spermatozoa through the zona $(P<0.005)$ (Table 2$)$. Vole spermatozoa also passed through the zonae of $10(16 \%)$ of 61 hamster oocytes, without acrosome reaction, and never fused with the oocytes (data not shown). Vole spermatozoa could also penetrate the zonae of mouse zygotes and two-cell embryos (Fig. 5), although the zonae of two-cell embryos were less penetrable by spermatozoa than those of oocytes and zygotes $(P<0.005)$ (Table 3 ).

As mentioned, vole spermatozoa that had penetrated zonae could not penetrate into (fuse with) mouse vitellus. Mouse oocytes with vole spermatozoa within the perivitelline space were reinseminated with mouse spermatozoa. They penetrated both the zonae and vitelli of the majority of these oocytes (Table 4). The rates of fertilization (vitellus penetration) and polyspermy were not significantly different from those in oocytes without vole spermatozoa in the perivitelline space $(P>0.05)$.

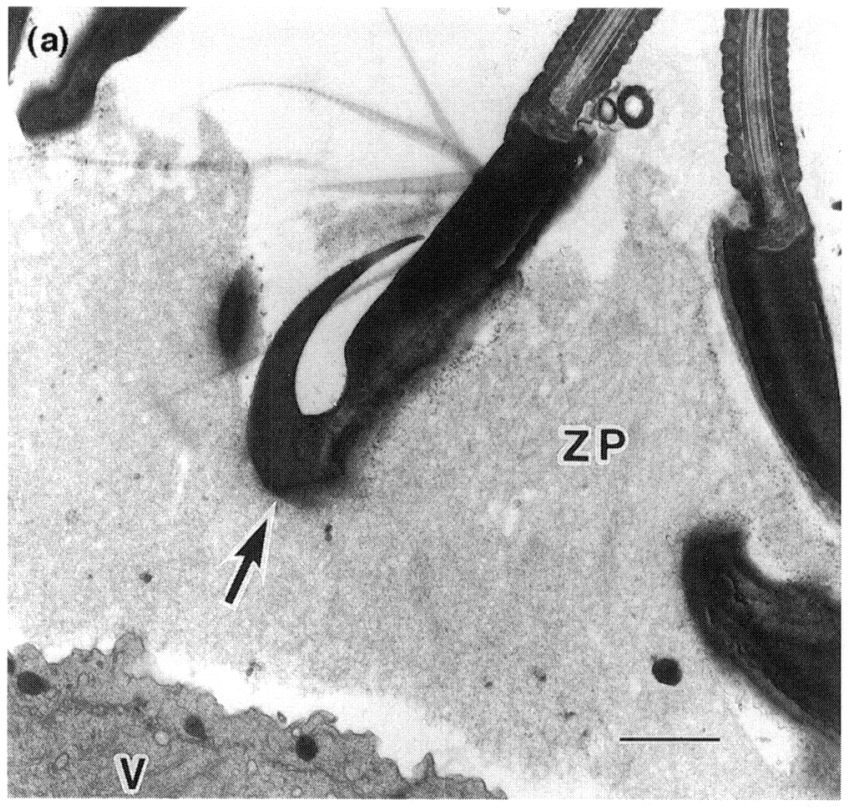

(b)

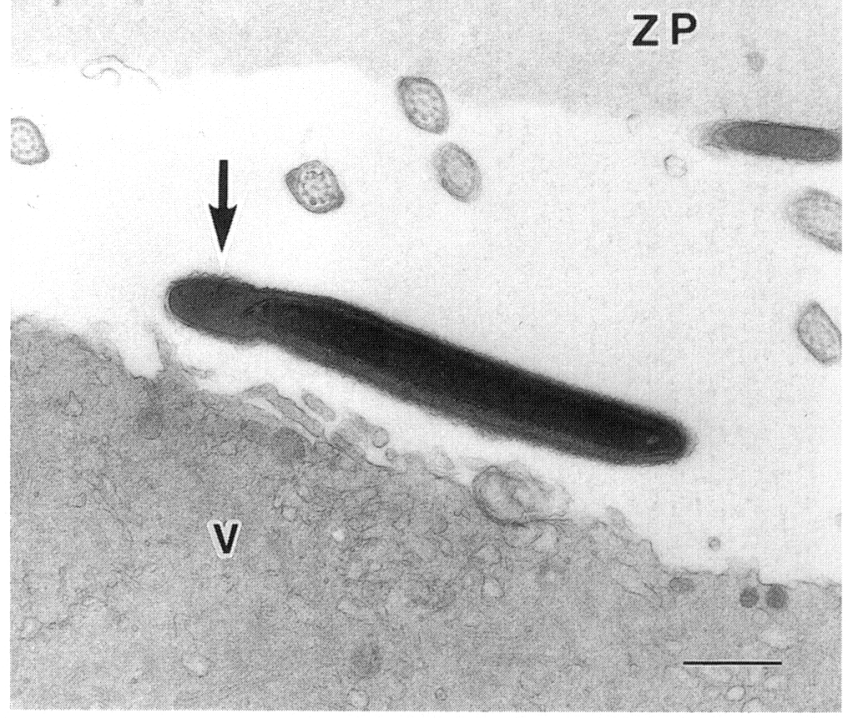

Fig. 4. (a) Frontal section of an acrosome-intact field vole sperm head in the mouse zona pellucida. Scale bar represents $I \mu \mathrm{m}$. (b) Transverse section of an acrosome-intact field vole spermatozoon in the perivitelline space of a mouse oocyte. An arrow indicates the intact acrosome. Scale bar represents $1 \mu \mathrm{m}$. The thinness of the zona pellucida is probably due to shrinkage during dehydration and embedding of specimens. V: oocyte vitellus; $\mathrm{ZP}$ : zona pellucida.

\section{Discussion}

The present study demonstrates that field vole spermatozoa, like the spermatozoa of other mammals, undergo the acrosome reaction before penetrating the zona pellucidae of homologous oocytes, whereas they cross the zonae of other species, the mouse and hamster, without undergoing the reaction. It was not surprising that such spermatozoa could not fuse with the mouse oocyte vitellus because acrosome-intact spermatozoa 
Table 2. Penetration of vole spermatozoa through mouse and vole zona pellucida in the presence of proteinase/hyaluronidase inhibitors

\begin{tabular}{|c|c|c|c|c|}
\hline Oocytes of & Inhibitor & Concentration & $\begin{array}{l}\text { Total number of } \\
\text { oocytes examined } \\
\text { (Expt number) }\end{array}$ & $\begin{array}{l}\text { Number }(\%) \text { of eggs } \\
\text { with spermatozoa in } \\
\text { the perivitelline space }\end{array}$ \\
\hline Vole & $\begin{array}{l}\text { Leupeptin } \\
\text { SBTI } \\
\text { Myocrisin } \\
\text { None (Control) }\end{array}$ & $\begin{array}{l}0.1 \mathrm{mmol}^{-1} \\
0.1 \mathrm{mg} \mathrm{m}^{-1} \\
0.1 \mathrm{mg} \mathrm{m}^{-1}\end{array}$ & $\begin{array}{l}15(2) \\
11(2) \\
20(2) \\
15(2)\end{array}$ & $\begin{array}{l}0(0)^{\mathrm{a}} \\
0(0)^{\mathrm{a}} \\
3(15.0)^{\mathrm{a}} \\
\text { II }(73.3)^{\mathrm{b}}\end{array}$ \\
\hline Mouse & $\begin{array}{l}\text { Leupeptin } \\
\text { SBTI } \\
\text { Myocrisin } \\
\text { None (Control) }\end{array}$ & $\begin{array}{l}1 \mathrm{mmol} \mathrm{l}^{-1} \\
1 \mathrm{mg} \mathrm{ml}^{-1} \\
1 \mathrm{mg} \mathrm{ml}^{-1} \\
\end{array}$ & $\begin{array}{r}72(3) \\
68(3) \\
73(3) \\
105(3)\end{array}$ & $\begin{array}{l}63(87.5)^{*} \\
61(89.7)^{*} \\
64(87.7)^{*} \\
91(86.7)^{*}\end{array}$ \\
\hline
\end{tabular}

aversus ${ }^{b}: P<0.005$

*No significant difference between values with asterisks $(P>0.05)$.

SBTl: Soybean trypsin inhibitor.

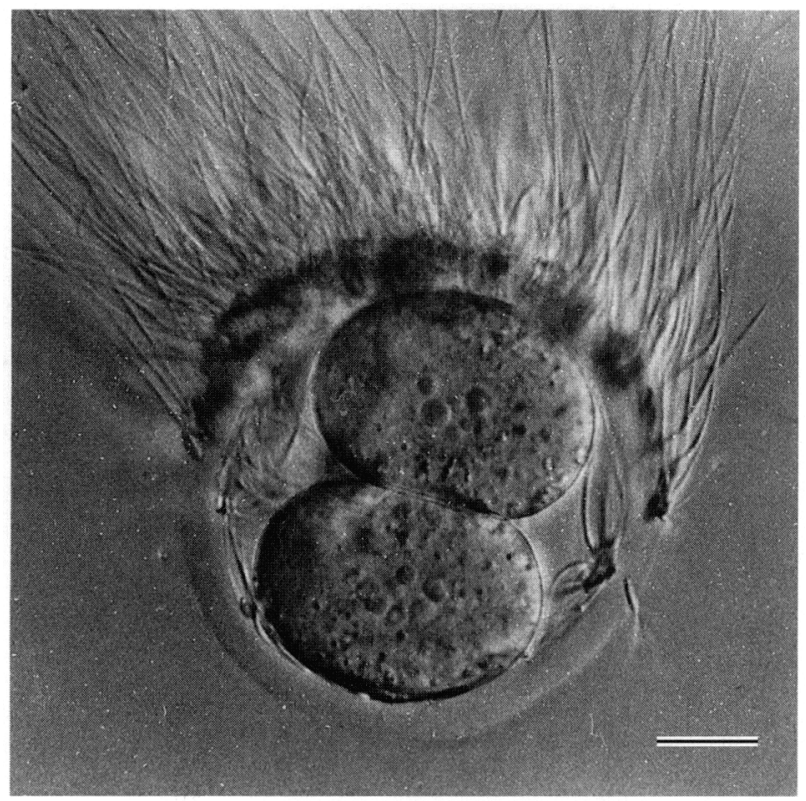

Fig. 5. Mouse two-cell embryo with field vole spermatozoa within the perivitelline space. Scale bar represents $25 \mu \mathrm{m}$.

cannot fuse even with homologous oocyte plasma membranes (Yanagimachi, 1988).

Zona penetration by spermatozoa is not strictly speciesspecific as evidenced by the occurrence of hybrids between closely related species (Gray, 1954), but in general spermatozoa of remote species cannot bind to and penetrate through zonae of other species. Evolutionary distance, however, is not necessarily related to the success or failure of sperm-zona binding or zona penetration by spermatozoa (Yanagimachi, 1994). Ram spermatozoa, for example, can penetrate through bovine zonae (Slavik et al., 1990); goat spermatozoa can cross bovine zonae (Slavik and Fulka, 1992) and human spermatozoa can penetrate through hamster zonae (Yoshimatsu et al., 1988). In none of above cases, however, was the acrosomal status of penetrating spermatozoa investigated, perhaps due to the
Table 3. Penetration of field vole spermatozoa through zonae pellucidae of mouse oocytes, zygotes and two-cell embryos

\begin{tabular}{lcc}
\hline Mouse eggs & $\begin{array}{c}\text { Total number of } \\
\text { eggs inseminated } \\
\text { (Expt number) }\end{array}$ & $\begin{array}{c}\text { Number }(\%) \text { of eggs } \\
\text { with spermatozoa in } \\
\text { the perivitelline space }\end{array}$ \\
\hline Unfertilized & $216(7)$ & $199(92.1)^{\mathrm{a}}$ \\
Zygote & $197(7)$ & $185(93.9)^{\mathrm{a}}$ \\
Two-cell & $173(7)$ & $90(52.0)^{\mathrm{b}}$ \\
\hline
\end{tabular}

aversus ${ }^{\mathrm{b}}: P<0.005$

Table 4. Penetration of mouse spermatozoa into the vitelli of mouse oocytes previously inseminated with field vole spermatozoa

\begin{tabular}{|c|c|c|c|}
\hline $\begin{array}{l}\text { Mouse oocytes } \\
\text { with }(+) \text { or } \\
\text { without }(-) \\
\text { vole spermatozoa } \\
\text { within perivitelline } \\
\text { space }\end{array}$ & $\begin{array}{l}\text { Total number } \\
\text { oocytes } \\
\text { inseminated } \\
\text { (Expt number) }\end{array}$ & $\begin{array}{c}\text { Number }(\%) \\
\text { of vitelli } \\
\text { penetrated }\end{array}$ & $\begin{array}{c}\text { Number }(\%) \\
\text { of polyspermic } \\
\text { eggs }\end{array}$ \\
\hline+ & $103(5)$ & $85(82.5)^{\mathrm{a}}$ & $5(4.9)^{a}$ \\
\hline- & $74(5)$ & $58(78.4)^{b}$ & $3(4.1)^{b}$ \\
\hline
\end{tabular}

"versus ": $P<0.05$.

presumption by previous investigators that only acrosomereacted spermatozoa are able to pass through the zona. The study reported here shows that field vole spermatozoa can cross the zona of mouse and hamster oocytes without first undergoing an acrosome reaction. It is generally assumed that zona penetration by mammalian spermatozoa is achieved by zona-hydrolysing acrosomal enzymes, zona lysins (for example, acrosin), which are presumably bound tightly on the inner acrosomal membrane of acrosome-reacted spermatozoa 
(O'Rand et al., 1986). Since the frontal edge of acrosomereacted sperm head is sharply pointed, a thrusting power (shearing force) generated by the vigorously motile sperm flagellum, which is transmitted to the head, may be sufficient to push through the meshwork of the zona matrix without enzyme activity (Baltz et al., 1988; Bedford, 1991; Yanagimachi 1994). The fact that acrosome-intact vole spermatozoa can penetrate mouse zonae even in the presence of proteinase/ hyaluronidase inhibitors seems to suggest that mechanical force is enough for vole spermatozoa to cross the zonae without using hydrolysing enzymes (for example, acrosin and hyaluronidase) that are present on the sperm plasma membrane over the acrosome (Talbot, 1985; Overstreet et al., 1995). We cannot explain why acrosome-intact vole spermatozoa penetrate mouse zonae very efficiently, whereas the same spermatozoa penetrate vole zonae only after undergoing the acrosome reaction. Perhaps mouse zonae are 'softer' than vole zonae and the high concentration of the vole spermatozoa $\left(1 \times 10^{7}\right.$ cells $\mathrm{ml}^{-1}$ ) may increase the chance of their making slits through the mouse zona. Hamster zonae, which are penetrable by vole spermatozoa but to a lesser degree than mouse zonae, may have intermediate stiffness. This point must be investigated further. What we want to stress in this paper is that under special circumstances spermatozoa can penentrate zonae without the assistance of the acrosome reaction or the presence of hydrolysing enzymes on sperm surfaces. Under ordinary circumstances mechanical force alone is not sufficient for successful zona penetration by spermatozoa, but it must be an essential component of this fertilization process (Yanagimachi, 1994).

This work was supported in part by a Grant-in-Aid for Scientific Fund (No. 07456131) from the Ministry of Education, Science, Sports and Culture, Japan.

\section{References}

Baltz JM, Katz DF and Cone RA (1988) Mechanics of sperm-egg interaction at the zona pellucida Biophysical Journal 54 643-654

Bedford JM (1991) The coevolution of mammalian gametes. In A Comparative Overview of Mammalian Fertilization pp 3-35 Eds BS Dunbar and MG O'Rand. Plenum Press, New York

Goto N and Hashizume R (1978) Pattern of ovulation in Microtus montebell Journal of Mammalogical Society of Japan 7 181-189
Goto N, Hashizume R and Sai I (1977) Litter size and vaginal smear in Microtus montebelli Journal of Mammalogical Society of Japan 7 75-85

Gray AP (1954) Mammalian Hybrids Farnham Royal Bucks, Commonwealth Agriculture Bureau, Farnham, Bucks

Imai S and Ogimoto K (1988) Flagellate protozoa in the digestive tract of the Japanese field vole, Microtus montebelli Japanese Journal of Zootechnical Science $59351-356$

Kudo $\mathrm{H}$ and Oki $\mathrm{Y}$ (1984) Microtus species as new herbivorous laboratory animal: reproduction; bacterial flora and fermentation in the digestive tract; and nutritional physiology Veterinary Research Communications 8 77-91

Obara $Y$ and Goto N (1988) Utilization of endogenous nitrogen in the Japanese field vole, (Microtus montebelli) Japanese Journal of Zootechnical Science $\mathbf{5 9}$ $319-323$

Overstreet JW, Lin Y, Yudin AI, Meyers SA, Primakoff P, Myles DG, Katz DF and Vandevoort CA (1995) Location of the $\mathrm{PH}-20$ protein on acrosome-intact and acrosome-reacted spermatozoa of cynomolgus macaques Biology of Reproduction 52 105-114

O'Rand MG, Welch JE and Fisher SJ (1986) Sperm membrane and zona pellucida interactions during fertilization. In Molecular and Cellular Aspects of Reproduction pp 131-144 Eds DS Dhindsa and OP Bahl. Plenum Press, New York

Slavik T and Fulka J (1992) In vitro fertilization of intact sheep and cattle oocytes with goat spermatozoa Theriogenology 38 721-726

Slavik T. Pavlok A and Fulka J (1990) Penetration of intact bovine ova with ram sperm in vitro Molecular Reproduction and Development 25 345-347

Talbot $\mathrm{P}$ (1985) Sperm penetration through oocyte investments in mammals American Joumal of Anatomy 174 331-346

Toyoda $Y$ and Chang MC (1974) Fertilization of rat eggs in vitro by epididymal spermatozoa and the development of eggs following transfer Journal of Reproduction and Fertility $369-22$

Toyoda Y, Yokoyama M and Hoshi T (1971) Studies on the fertilization of mouse eggs in vitro Japanese Journal of Animal Reproduction 16 147-151

Wakayama T, Maruyama Y, Imamura K and Fukuta K (1993) Penetration of the zona pellucida of eggs of different species by spermatozoa of the Japanese field vole, Microtus montebelli Journal of Reproduction and Development 39 319-323

Wakayama T, Suto J, Matsubara Y, Imamura K, Fukuta K, Toyoda Y, Kurohmaru M and Hayashi $Y$ (1995a) In vitro fertilization and embryo development of Japanese field vole, Microtus montebelli Journal of Reproduction and Fertility 104 63-68

Wakayama T, Suto J, Imamura $K$, Goto S, Fukuta K, Ogura A, Asano T, Kurohmaru M and Hayashi $Y$ (1995b) Copulatory ovulation and subsequent fertilization in vivo and in vitro in the Japanese field vole Journal of Mammalian Ova Research 12 S14 (in Japanese)

Yanagimachi $\mathbf{R}$ (1988) Sperm-egg fusion. In Current Topics in Membranes and Transport vol. 32 pp 3-43 Eds N Duzgunes and F Bronner. Academic Press, San Diego

Yanagimachi R (1994) Mammalian Fertilization. In The Physiology of Reproduction 2nd edn pp 189-317 Eds E Knobil and JD Neill. Raven Press, New York

Yoshimatsu N, Yanagimachi R and Lopata A (1988) Zona pellucidae of saltstored hamster and human eggs: their penetrability by homologous and heterologous spermatozoa Gamete Research 21 115-126 